African Crop Science Journal by African Crop Science Society is licensed under a Creative Commons Attribution 3.0 Uganda License. Based on a work at www.ajol.info/ and www.bioline.org.br/cs DOI: http://dx.doi.org/10.4314/acsj.v25i2.2

\title{
EFFICACY OF RICE HUSK ASH AGAINST RICE WEEVIL AND LESSER GRAIN BORER ON STORED WHEAT
}

\author{
G.O. OTITODUN ${ }^{1}$, G.P. OPIT, S.I. NWAUBANI ${ }^{1}$ and E.U. OKONKWO ${ }^{1}$ \\ Department of Entomology and Plant Pathology, Oklahoma State University, 127 Noble Research Center, \\ Stillwater, Oklahoma 74078-3033, USA \\ ${ }^{1}$ Nigerian Stored Products Research Institute Headquarters, Km 3, Asa Dam Road, P.M.B. 1489, Ilorin, \\ Kwara State, Nigeria \\ Corresponding author: george.opit@okstate.edu
}

(Received 7 May, 2016; accepted 5 May, 2017)

\begin{abstract}
Rice husks are an environmental nuisance, but have a high concentration of silica. Therefore, rice husk ash (RHA), a by-product of burning rice husks, may have potential for control of stored grain insect pests. The objective of this study was to determine efficacy of RHA from "Mr. Harry" rice variety against Rhyzopertha dominica and Sitophilus oryzae. Low (RHAL) and high (RHAH) application rates of RHA, corresponding to 0.5 and $1 \mathrm{~g} \mathrm{~kg}^{-1}$, respectively, were evaluated against both weevils on wheat. Insecto ${ }^{\circledR}$, a commercial DE, was tested as a standard check. This study was conducted at Oklahoma State University, Stillwater, OK, USA. RHAH caused 10.3 and $91.1 \%$ mortalities of adult $R$. dominica and $S$. oryzae, respectively, after a 14-day exposure period. After the same time period, Insecto ${ }^{\circledast}$ caused $R$. dominica and $S$. oryzae mortalities of 63.4 and $100 \%$, respectively. For $S$. oryzae, Insecto ${ }^{\circledR}, \mathrm{RHAH}$ and RHAL caused $\mathrm{F}_{1}$ progeny suppression of 95.2, 63.8 and 46\%, respectively. Similar numbers of $R$. dominica progeny were produced in the control, RHAL, and RHAH treatments $(78.4,92.9$ and 64.3, respectively); fewer progeny were produced in the Insecto treatment (20.3). The silica in RHA used was $87.1 \%$. In relation to particle size, the mean, minimum, and maximum particle sizes for RHA were 112.4, 16.2 , and $550.1 \mu \mathrm{m}$, respectively. Based on this study, RHA may have potential for refinement into an effective protectant for use in management of stored grain insect pests in sub-Saharan Africa.
\end{abstract}

Key Words: Oryza sativa, protectant, Rhyzopertha dominica, silica, Sitophilus oryzae

\section{RÉSUMÉ}

Les enveloppes de riz constituent une ménace environnementale, mais ont une forte concentration en silice. Toutefois, la cendre de l'enveloppe du riz (RHA), un sous-produit de l'incinération des enveloppes du riz, pourrait être un potentiel pour le contrôle des insectes de grains sotckés. L'objectif de cette étude était de déterminer l'efficacité de RHA de la variété "Mr. Harry" du riz contre Rhyzopertha dominica et Sitophilus oryzae. Faible (RHAL) et forte (RHAH dose d'application de RHA, correspondant respectivement à 0,5 et $1 \mathrm{~kg}^{-1}$, étaient évaluées à la fois contre les charançons du blé. Insecto ${ }^{\circledR}$, un pesticide DE commercial, était testé comme un contrôle standard. Cette étude a été conduite à l'université de l'Etat de Oklahoma, Stillwater, OK, USA. La forte dose (RHAH) a causé 10,3 et $91,1 \%$ de mortalités des adultes de $R$. dominica et $S$. oryzae, respectivement, après une période de 14 jours d'exposition. Après la même période de temps, Insecto ${ }^{\circledR}$ a causé une mortalité de $63,4 \%$ and $100 \%$ chez $R$. dominica et $S$. oryzae, respectivement. Insecto@, RHAH et RHAL ont causé une suppression de 95,2 et $63,8 \%$ chez les descendants $\mathrm{F}_{1}$ de $S$. oryzae. Les mêmes nombres de descendants de $S$. dominica ont été observés sous le contrôle, les traitements RHAL et RHAH (78,4, 92,9 et 64,3, respectivement); peu de descendants étaient produits sous le traitement à Insecto ${ }^{\circledR}(20,3)$. Le taux de silice dans la RHA utilisée, était $87,1 \%$. En ce qui 
concerne la taille des particules, la taille moyenne, minimale et maximale des particules de RHA, étaient 112,4, 16,2 , et $550,1 \mu \mathrm{m}$, respectivement. De cette étude, RHA pourrait être un potentiel pour l'amélioration du pesticide efficace utilisé dans la gestion des insectes de grains sotckés en Afrique sub-Saharienne.

Mots Clés: Oryza sativa, protecteur, Rhyzopertha dominica, silice, Sitophilus oryzae

\section{INTRODUCTION}

Rice (Oryza sativa L.) is the most cultivated cereal crop all over the world (FAO, 2008). It absorbs silica $\left(\mathrm{SiO}_{2}\right)$ from soil and assimilates it into plant structures during growth (Smith and Kamwanja, 1986). This results in a high concentration of silica $(80-90 \%)$ in the husks of rice kernels (McFarlane, 1989; Siddique, 2008). Rice husks are a major by-product of rice processing mills and can constitute an environmental nuisance in and around the mills, if not properly disposed. Finding alternative uses for rice husks is a logical approach to mitigating their negative environmental impacts.

With a high concentration of silica, rice husk ash (RHA), a by-product of burning rice husks may be a grain protectant against major stored grain insect pests. This is because silica-rich materials like diatomaceous earth (DE) have been shown to control storedproduct beetle pests (Nwaubani et al., 2014; Otitodun et al., 2015). The huge quantities of rice husks produced during milling of rice implies that RHA would be a readily available and inexpensive tool for smallholder farmers for stored grain pest management.

Nigeria is West Africa's largest rice producer (Goni and Amaza, 2006) and rice is cultivated in all agro-ecological zones, from the mangrove and swampy ecosystems of the River Niger in the coastal areas, to the dry zones of the Sahel in the North (Akande, 2003). This implies that RHA, if proven effective for stored-grain insect pest control, would be readily available and widely adopted in Nigeria.

Use of RHA for stored grain protection is not a new idea. Farmers in India and Japan have used it for stored grain protection (Krishnamurthi and Rao, 1950; McFarlane,
1989). However, there is need for information on the insecticidal capabilities of RHA from popularly cultivated rice varieties in West Africa, especially application rates that will effectively control stored-grain insect pests. Additionally, information on geochemical composition, particle sizes and toxicology of RHA is lacking.

Rhyzopertha dominica (F.) (Coleoptera: Bostrichidae) and Sitophilus oryzae (L.) (Coleoptera: Curculionidae) are two key primary stored-grain insect pests in subSaharan Africa (Garcia et al., 2005; Chijindu and Boateng, 2008; Nwaubani and Fasoranti, 2008). In many parts of Nigeria's Savannah belts, wheat growing and storage is the key driver of economic development and food security (Faliki et al., 2009). Therefore, stored-grain insect pest infestations in stored wheat could be mitigated by the use of RHA.

In Nigeria, Adebayo and Ibikunle (2014) studied the effectiveness of RHA against Callosobruchus maculatus (F.) (Coleoptera: Chrysomelidae) and Sitophilus zeamais Motsch. (Coleoptera: Curculionidae), on cowpea and maize, respectively. However, the dose rate used by these authors, $(2 \mathrm{~g}$ per 20 cowpea seeds) was too high for practical application. Gaps in knowledge still exist regarding efficacy of RHA from popularly grown rice varieties against other storedproducts insect pests in the West Africa subregion. Therefore, the objective of this study was to determine the efficacy of RHA from a popularly grown rice variety called "Mr. Harry" on adult mortality and $\mathrm{F}_{1}$ progeny reduction of two key stored-grain beetles $R$. dominica and $S$. oryzae, and to determine the chemical composition and particle sizes of the RHA used. 


\section{MATERIALS AND METHODS}

Rearing of insects. Rhyzopertha dominica and $S$. oryzae, used in this study were originally collected near Payne Co., OK, U.S.A. Both insects were reared on a mixture of $95 \%$ whole-wheat kernels and 5\% Brewer's yeast (wt/wt) at $28 \pm 1{ }^{\circ} \mathrm{C}$ and $65 \pm 5 \%$ relative humidity. Voucher specimens of $R$. dominica and $S$. oryzae used in this study were deposited in the K. C. Emerson Entomology Museum at Oklahoma State University (OSU), Stillwater, OK, U.S.A., under lot numbers 104 and 137, respectively. This study was conducted at OSU Stored Product Entomology Laboratory.

Rice husk ash (RHA). Ten kilogrammes of rice husks from a white long grain variety locally known as "Mr. Harry" were collected from a farm in Mbanaa, Ejura in Sekyedumase municipality, Ashanti Region of Ghana; one of the rice growing areas in Ghana. The husks were sun-dried, piled into a heap, set on fire, and allowed to burn completely under the sun. Open flame temperatures were in the 320-900 ${ }^{\circ} \mathrm{C}$ range (McCaffrey, 1979). The burnt ash was allowed to cool to $\sim 25^{\circ} \mathrm{C}$ temperature before it was packaged in Ziploc bags, and shipped to Oklahoma State University. Before the experiment, RHA was sieved with U.S. Standard \#60 sieve (0.250-mm openings) (Seedburo Equipment Company, Chicago, IL) to obtain fine particles.

Wheat samples. Uninfested, pesticide-free hard red winter wheat grain (Triticum aestivum L., variety "Endurance"), cultivated and purchased in Oklahoma, USA, was used for the study. The wheat grain was cleaned by sieving with U.S. Standard \#14 sieve (1.4-mm openings) to remove dockage. Damaged kernels were removed and discarded by handpicking.

Bioassays. Wheat used was conditioned to a moisture content of $11.5 \%$ by equilibrating for 18 days prior to the commencement of the experiment. Equilibration was conducted at laboratory temperatures $\left(23 \pm 0.02^{\circ} \mathrm{C}\right)$ in a plastic box $(42 \mathrm{~cm} \times 29 \mathrm{~cm} \times 24 \mathrm{~cm})$ that contained saturated $\mathrm{NaNO}_{2}$ solution beneath its false floor, to maintain $63 \pm 5 \% \mathrm{RH}$ (Winston and Bates, 1960). After wheat equilibration, two lots of $100 \mathrm{~g}$ of wheat were placed separately in 360-ml cylindrical glass jars, and admixed with RHA at dose rates of $0.05 \mathrm{~g} 100$

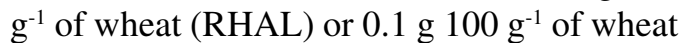
(RHAH), i.e. 500 or $1,000 \mathrm{ppm}$, respectively. The third lot of $100 \mathrm{~g}$ of wheat was placed in a 360-ml cylindrical glass jar, and admixed with Insecto $®$ DE at a dose rate of $0.1 \mathrm{~g}^{100 \mathrm{~g}^{-1} \text { of }}$ wheat. Another lot of $100 \mathrm{~g}$ of wheat that was not treated was placed in a $360-\mathrm{ml}$ jar containing wheat for the negative control. The jars were manually shaken vigorously for approximately 3 minutes, to achieve proper and uniform coating of the grains with the various dusts, where applicable.

From each of the treated $100 \mathrm{~g}$ lots, nine 10-g samples were placed in cylindrical plastic vials $(3.5 \mathrm{~cm}$ diameter, $6 \mathrm{~cm}$ high). Nine additional vials, each containing $10 \mathrm{~g}$ of untreated wheat served as vials for the control. Subsequently, 20 adults of mixed sexes and ages, of $S$. oryzae, were placed in each vial. Each vial was closed using a cap lid, which had a $1.5-\mathrm{cm}$ diameter hole that was covered with a screen (U.S. \#40 mesh) to allow aeration and prevent insects from escaping. The top third of the inner surface of each vial was coated with Fluon ${ }^{\circledR}$ (polytetrafluoroethylene; Northern Products, Woonsocket, RI) to prevent insects from climbing up and resting on the cap lids.

The same procedure was repeated for $R$. dominica. Vials for S. oryzae and R. dominica were randomly placed in black plastic boxes (42 $\mathrm{cm} \times 29 \mathrm{~cm} \times 24 \mathrm{~cm}$ ) painted black to maintain dark conditions. The boxes contained a saturated $\mathrm{NaNO}_{2}$ solution below perforated false floors to maintain $63 \pm 5 \% \mathrm{RH}$.

There were six boxes in total (one box for each temporal block for each beetle species), each box containing a total of 36 vials for each 
insect species. The boxes were prepared on three different dates, i.e., the experiment had three temporal replications. The boxes were placed in an incubator maintained at $30 \pm 1{ }^{\circ} \mathrm{C}$, and had $63 \pm 5 \% \mathrm{RH}$ conditions inside them, to simulate the hot dry ambient conditions in the wheat producing Savannah Belt of Northern Nigeria. Temperature and relative humidity inside the boxes were monitored using $\mathrm{HOBO}$ data loggers (Onset Computer Corporation, Bourne, MA; model U12-011).

For each box, three of the nine treated vials for each treatment and species; and three of the nine untreated control vials were examined for insect mortality at 7 and 14 days, posttreatment (here admixing any of the protectants with wheat is referred to as "treatment"). Insects that did not move spontaneously or respond to slight pressure applied using a blunt probe were considered dead (Dyte and Forster, 1973).

Fourteen days after addition of the insects to the treated and untreated wheat, contents (wheat) in the remaining 3 vials were sieved to remove all insects (dead and alive), and then the vials were closed and returned to the incubator for an additional 54 days (68 days post-treatment) before the number of $F_{1}$ progeny in each vial was determined (Nwaubani, 2006). Reduction in progeny production relative to the control was calculated using the formula of Arthur and Throne (2003):

Where:

$\operatorname{RPP}(\%)=\left(1-\left(\frac{\text { number of } F 1 \text { in treatment }}{\text { number of } F 1 \text { in control }}\right)\right)+100$

$\mathrm{RPP}=$ reduction in progeny production

The experimental design for determining 7 - and 14-day mortality and 68-day progeny production was a randomised complete block design (RCBD), with subsampling (3 vials associated with each replication comprised subsamples).
Mineralogy and particle size analyses. Samples of RHA were analysed to determine their chemical composition (Acme Analytical Laboratories Ltd, Vancouver, Canada). This involved analysis of 0.1 -g samples using Inductively Coupled Plasma Emission Spectroscopy, following lithium metaborate/ tetraborate fusion and dilute nitric digestion for determining total abundance of major oxides and several minor elements. For determining particle sizes, images were taken using a scanning electron microscope and were analysed using an image analysis program called AnalySIS (Intertek, Allentown, PA, U.S.A.). Fifty particles were measured for each sample.

Data analysis. Data for $R$. dominica and $S$. oryzae were analysed separately. Mortality data for 7- and 14-day exposure periods were corrected using Abbot's formula (Abbot, 1925). All statistical procedures were accomplished using Statistical Analysis System software (SAS Institute, 2013). PROC MIXED was used for a two-way analysis of variance (ANOVA) to determine the effects of treatments and exposure interval on adult insect mortality.

To stabilise variances, percentage data were transformed using the square root of the arcsine; untransformed data are reported to simplify interpretation. Where appropriate, the square root transformation was used to stabilise variances in relation to progeny production (number of progeny) data, but untransformed data are reported. The significance of mean differences was determined by Tukey's HSD (honest significant difference) test at $\mathrm{P}<0.05$.

\section{RESULTS}

Mortality and $F_{1}$ progeny suppression in $\boldsymbol{R}$. dominica. Rice husk ash applied at both low and high rates (RHAL and RHAH) resulted in adult $R$. dominica corrected mortalities that did not exceed $10.3 \%$ for both the 7 - and $14-$ 
day exposure periods (Fig. 1A). Mortalities caused by Insecto ${ }^{\circledR}$ for the two exposure periods were 40.4 and $63.4 \%$, respectively (Fig. 1A; Table 1). The RHAL and RHAH treatments had little effect on $R$. dominica $\mathrm{F}_{1}$ progeny suppression (Fig. 1B; Table 1). Significantly fewer progeny were produced in the Insecto treatment (20.3). Numerically, there were $18.5 \%$ more $R$. dominica progeny in the RHAL treatment than the control. However, there were 18 and $74.1 \%$ fewer progeny in the RHAH and Insecto treatments, respectively, than in the control.
Mortality and $F_{1}$ progeny suppression in $S$. oryzae. The RHAL treatment resulted in adult S. oryzae corrected mortalities of 14.5 and $68.0 \%$ for the 7 - and 14-day exposure periods, respectively (Fig. 2A; Table 2). Mortalities for the RHAH treatment were 46.1 and $91.1 \%$ for the 7- and 14-day exposure periods, respectively (Fig. 2A; Table 2). Corrected mortalities for Insecto were $100 \%$ for both the 7- and 14-day exposure periods (Fig. 2A; Table 2). The RHAL and RHAH treatments suppressed $S$. oryzae progeny production (population increase) by only 46.0 and $63.8 \%$
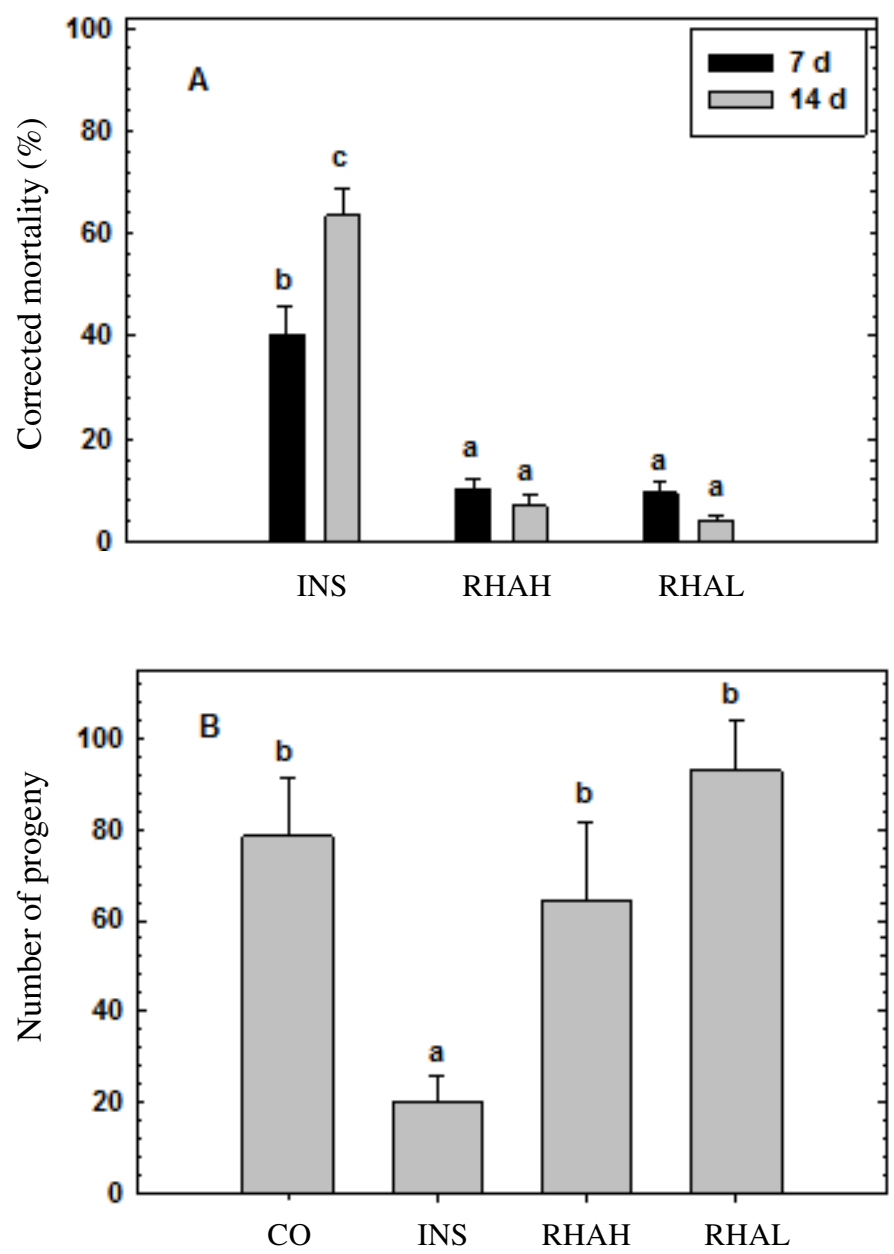

Figure 1. Corrected mortality (mean $\pm \mathrm{SE}$ ) (A) and number of $R$. dominica progeny (B) found in vials containing wheat treated using different protectants. $\mathrm{CO}$ - control; INS - Insecto; RHAH - rice husk ash at the high rate $\left(1,000 \mathrm{mg} \mathrm{kg}^{-1}\right)$; RHAL - rice husk ash at the low rate $\left(500 \mathrm{mg} \mathrm{kg}^{-1}\right)$. Means followed by different lowercase letters within each figure are significantly different $(\mathrm{P}<0.05)$. 
suppression, respectively (Figs. $2 \mathrm{~B}$ and $2 \mathrm{C}$; Table 2). On the other hand, Insecto ${ }^{\circledR}$ was effective at reducing progeny production (population increase) by $S$. oryzae by up to 95.2\% (Fig. 2C; Table 2).

Mineralogy and particle sizes of rice husk ash. The amount of silica $\left(\mathrm{SiO}_{2}\right)$ found in RHA was 87.1 (Table 3). Compounds with the second and third highest concentrations in RHA were phosphorus pentoxide $\left(\mathrm{P}_{2} \mathrm{O}_{5}\right.$; $4.46 \%)$ and magnesium oxide ( $\mathrm{MgO} ; 2.25 \%)$, respectively (Table 3 ). In relation to elements in RHA, barium (Ba; $0.02 \%$ ) was also found (Table 3). The mean, minimum, and maximum particle sizes for RHA were 112.4, 16.2, and $550.1 \mu \mathrm{m}$; while the size distribution was $16-$ 30 (30\%), 31-60 (30\%), 61-200 (16\%), and

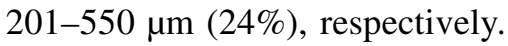

\section{DISCUSSION}

It is clear that none of the three treatments, RHAL, RHAH, or Insecto, was effective against adult $R$. dominica. Other inert dusts such as certain types of DE and Riverbed Sand have been found ineffective against storedgrain insect pests. Otitodun et al. (2015) found that Riverbed Sand caused only $9.5 \%$ mortality in $R$. dominica after 7 days in treated wheat.

TABLE 1. ANOVA results for main effects and interactions for corrected mortality of $R$. dominica and for effects of protectant on number of progeny of $R$. dominica

\begin{tabular}{lrrr}
\hline & df & F & \multicolumn{1}{c}{$\mathrm{P}$} \\
\hline Corrected mortality & & & \\
& & & $<0.01$ \\
Type of protectant & 2,10 & 0.2 & 0.7 \\
Exposure time & 1,10 & 7.8 & $<0.01$ \\
Type of protectant x exposure time & 2,10 & & \\
Progeny production & & & 0.03 \\
Type of protectant & 3,6 & 6.2 & \\
\hline
\end{tabular}

TABLE 2. ANOVA results for main effects and interaction for corrected mortality of $S$. oryzae, and for effects of protectant on number of progeny and percentage reduction in the number of progeny of $S$. oryzae

\begin{tabular}{lccc}
\hline & $\mathrm{df}$ & $\mathrm{F}$ & $\mathrm{P}$ \\
\hline Corrected mortality & & & \\
& & & \\
Type of protectant & 2,10 & 54.5 & $<0.01$ \\
$\begin{array}{l}\text { Exposure time } \\
\text { Type of protectant x exposure time }\end{array}$ & 1,10 & 14.0 & $<0.01$ \\
Progeny production & 2,10 & & \\
Type of protectant & 3,6 & 31.7 & $<0.01$ \\
$\begin{array}{l}\text { Percentage reduction } \\
\text { in progeny production }\end{array}$ & & & $<0.01$ \\
Type of protectant & 2,4 & 34.2 & \\
\hline
\end{tabular}



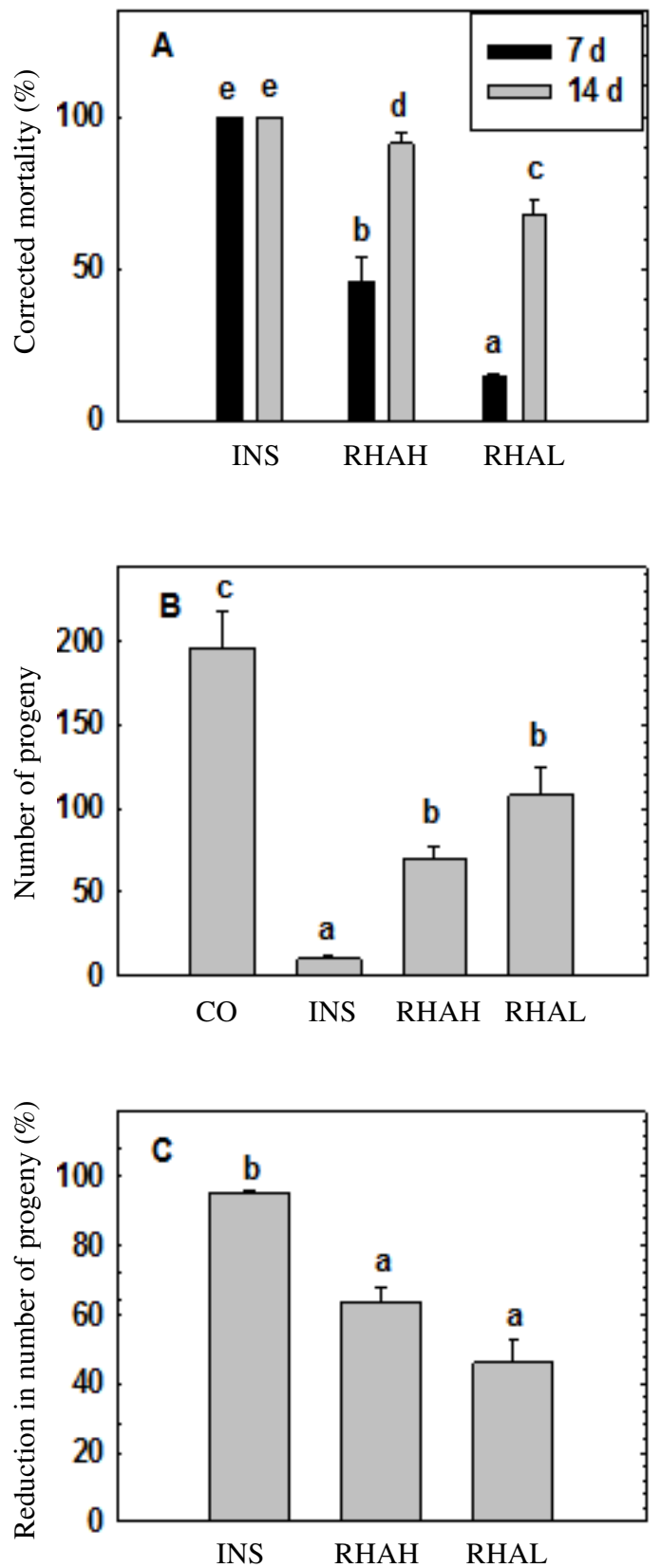

Figure 2. Corrected mortality (mean $\pm \mathrm{SE})(\mathrm{A})$, number of progeny (B), and percentage reduction in the number of progeny (C) of $S$. oryzae found in vials containing wheat treated using different protectants. $\mathrm{CO}$-control; INS - Insecto; RHAH - rice husk ash at the high rate $\left(1,000 \mathrm{mg} \mathrm{kg}^{-1}\right)$; RHAL - rice husk ash at the low rate $\left(500 \mathrm{~m} \mathrm{~kg}^{-1}\right)$. Means followed by different lowercase letters within each figure are significantly different $(\mathrm{P}$ $<0.05)$.
TABLE 3. Concentrations of compounds and elements found in rice husk ash (RHA)

\begin{tabular}{lcc}
\hline Group & Molar dilutions & Composition (\%) \\
\hline Compounds & & \\
$\mathrm{SiO}_{2}$ & 0.1 & 87.1 \\
$\mathrm{Al}_{2} \mathrm{O}_{3}$ & 0.01 & 0.34 \\
$\mathrm{Fe}_{2} \mathrm{O}_{3}$ & 0.01 & 0.39 \\
$\mathrm{MgO}$ & 0.01 & 2.25 \\
$\mathrm{CaO}$ & 0.01 & 2.11 \\
$\mathrm{Na}_{2} \mathrm{O}$ & 0.01 & 0.05 \\
$\mathrm{~K}_{2} \mathrm{O}$ & 0.01 & 1.61 \\
$\mathrm{TiO}_{2}$ & 0.01 & 0.10 \\
$\mathrm{P}_{2} \mathrm{O}_{5}$ & 0.01 & 4.46 \\
$\mathrm{MnO}_{\mathrm{O}}$ & 0.01 & 0.23 \\
$\mathrm{Cr}_{2} \mathrm{O}_{3}$ & 0.001 & $<0.001$ \\
Elements & & \\
$\mathrm{Ba}$ & & \\
\hline
\end{tabular}

Stathers (2002), found that diatomaceous earths (DEs) are not effective against Prostephanus truncatus (Horn) (Coleoptera: Bostrichidae) and other bostrichids, unless applied at high concentrations. According to data from this study, $R$. dominica was more tolerant to RHA than $S$. oryzae on wheat.

Although reasons for the relatively low susceptibility of bostrichids ( $R$. dominica included) to inert dusts are not well understood, their low mobility which results in reduced contact between the cuticle and dust particles (Athanassiou et al., 2005) is a plausible explanation. It could also be due to taxonomic differences in the nature of the cuticles of the two test species which caused differential rates of water loss (Nawrot et al., 1994). Nwaubani et al. (2014) and Stathers (2002) suggest other reasons for the higher tolerance of $R$. dominica to DEs.

In this study, RHAH and Insecto caused high mortality in S. oryzae. As for suppressing $S$. oryzae progeny production, RHAH was 
moderately effective whereas Insecto was highly effective (Figs. 2A and B). Mortalities of $S$. oryzae caused by RHAL and RHAH increased with exposure period (Fig. 2A). These data from the current study indicate extremely high increase in the effectiveness of RHA as exposure period increases. If this increase in effectiveness with time holds for periods beyond 14 days of exposure, it indicates that RHA is more effective and causes mortalities higher than $68.0 \%$ and $91.1 \%$ for RHAL and RHAH, respectively (Fig. 2A).

From this study, RHA induced greater adult mortality and higher $\mathrm{F}_{1}$ progeny suppression in S. oryzae than in R. dominica (Figs. 1 and 2). Fields and Korunic (2000) and, Arthur and Throne (2003) have clearly stated that stored grain beetles vary widely in susceptibility to inert dusts. Sitophilus spp. are usually ranked midway in susceptibility between small mobile insects, such as Cryptolestes spp. or Oryzaephilus spp. and $R$. dominica or Tribolium spp. that are more tolerant to inert dusts (Fields and Muir, 1996).

Data from this study reveal that the chemical compounds in RHA were mostly oxides (Table 3). Silica was the predominant compound $(87.1 \%)$ in the RHA used in this study. Silica $\left(\mathrm{SiO}_{2}\right)$ levels have been found to correlate significantly with efficacy in DE bioassays involving $S$. oryzae (Rojht et al., 2010). Although several mechanisms have been given to explain how DEs kill insects, it is generally accepted that they largely work through adsorption of the epicuticular wax of insects by silica, leading to desiccation and death (Athanassiou and Steenberg, 2007). Whether RHA used in this study also works in a similar manner as DEs needs to be determined.

According to data from this study, the mean, minimum, and maximum particle sizes for RHA used in this study were 112.4, 16.2, and $550.1 \mu \mathrm{m}$, respectively. These values are higher than those of Insecto $^{\circledR}$ by 6.89, 1.0, and $34.3 \mu \mathrm{m}$, respectively (Subramanyam $e t$ al., 1994; Arnaud et al., 2005).
One of the factors contributing to higher insecticidal values of inert dusts is smaller and more uniform particles (Korunic, 1997; Nwaubani et al.. 2014). Smaller particles tend to have greater surface to volume ratio, resulting in increased area of contact between particles and insect cuticle (Ebeling, 1971; McLaughlin, 1994; Korunic 1997, 1998). Bularafa DE, an inert dust from Nigeria, which was found to be highly effective against $S$. oryzae by Nwaubani et al. (2014) had mean, minimum, and maximum particle sizes of 4.3, 1.2 , and $13.5 \mu \mathrm{m}$, respectively. The fact that RHA, with larger and less uniform particles was nearly as effective as Bularafa and Insecto ${ }^{\circledR}$ DEs, may probably indicate its potential for stored-product insect pest management. Bularafa DE has a silica content of $80.98 \%$ (Nwaubani et al., 2014); whereas Insecto ${ }^{\circledast}$ has a silica content of $87.0 \%$ (Arnaud et al., 2005). The $87.1 \%$ silica content of RHA could be a major contributing factor in its high efficacy against $S$. oryzae.

With additional processing to produce smaller and more uniform particles, inclusion of additives such as $10 \%$ silica aerogel as in the case of Protect-It commercial DE (Kavallieratos et al., 2007), RHA formulations are likely to be made even more effective against stored product insect pests. Habeeb and Mahmud (2010), and Madrid et al. (2012) showed that grinding RHA to finer average particle size of $11.5 \mu \mathrm{m}$ from $63.8 \mu \mathrm{m}$ increased its specific surface area and efficacy.

Another possible way of increasing the efficacy of RHA is by calcination; a thermal treatment process in the absence of or presence of a limited supply of air or oxygen, under controlled temperature below $800^{\circ} \mathrm{C}$ to produce ash with silica mainly in amorphous form (Zhang and Malhotra, 1996).

There is need for further investigation of the reduction of particle size of RHA particles and calcination. Research is also necessary on how efficacy of RHA can be enhanced by combining it with botanicals such as D. tripetala or $P$. guineense or Nigeria-derived 
DEs, such as Bularafa DE to adequately improve its effectiveness against $R$. dominica, $S$. oryzae, and other stored-product insect pests.

RHA can be used to treat seed grains in Nigeria to ensure they are protected from mostly $S$. oryzae infestation and remain viable until planting time. However, toxicological tests need to be conducted to investigate the feasibility of using RHA to treat grains meant for food and feed.

\section{CONCLUSION}

The present study, conducted at $30^{\circ} \mathrm{C}$ and $63 \%$ $\mathrm{RH}$, conditions found in tropical regions, demonstrates that RHA has potential for use in the control of S. oryzae in cereal grains such as wheat under tropical storage conditions, and could provide farmers, grain aggregators and managers with a safe and environmentallyfriendly IPM tool for use in Nigeria and other parts of sub-Saharan Africa.

\section{ACKNOWLEDGEMENT}

The United States Department of AgricultureForeign Agricultural Service (USDA-FAS) for supporting the lead author under the 2011 Norman Borlaug Fellowship Program for Nigeria that enabled her to conduct research at Oklahoma State University. This work was funded in part with funds from the Oklahoma Agricultural Experiment Station (Project No. OKL02949). Mention of trade names or commercial products in this publication is solely for the purpose of providing specific information and does not imply recommendation or endorsement by Oklahoma State University, USDA-FAS, or Nigerian Stored Products Research Institute.

\section{REFERENCES}

Abbot, W.S. 1925. A method of computing the effectiveness of an insecticide. Journal of Economic Entomology 18(2):265-267.
Adebayo, R.A. and Ibikunle, O. 2014. Potentials of rice husk ash, cowdung ash and powdered clay as grain protectants against Callosobruchus maculatus $(\mathrm{F})$ and Sitophilus zeamais (Mots). Applied Tropical Agriculture 19(2):48-53.

Akande, T. 2003. An overview of Nigerian rice economy. Monograph published by the Nigerian Institution of Social and Economic Research (NISER), Ibadan, Nigeria.

Arnaud, L., Huong, T.T.L., Brostaux, Y. and Haubruge, E. 2005. Efficacy of diatomaceous earth formulations admixed with grain against populations of Tribolium castaneum. Journal of Stored Products Research 41(2):121-130.

Arthur, F.H. and Throne, J.E. 2003. Efficacy of diatomaceous earth to control internal infestations of rice weevil and maize weevil (Coleoptera: Curculionidae). Journal of Economic Entomology 96(2):510-518.

Athanassiou, C.G. and Steenberg, T. 2007. Insecticidal effect of Beauveria bassiana (Balsamo) Vuillemin (Ascomycota: Hypocreaes) in combination with three diatomaceous earth formulations against Sitophilus granarius (L.) (Coleoptera: Curculionidae). Biological Control 40(3): 411-416.

Athanassiou, C.G., Kavallieratos, N.G., Economou, L.P., Dimizas, C.B., Vayias, B.J., Tomanovic, S. and Milutinoviæ, M. 2005. Persistence and efficacy of three diatomaceous earth formulations against Sitophilus oryzae (Coleoptera: Curculionidae) on wheat and barley. Journal of Economic Entomology 98(4): 1404-1412.

Chijindu, E.N. and Boateng, B.A. 2008. Effect of Nutritional content of processed cassava Chips on Development of Prostephanus truncatus (Horn). World Journal of Agricultural Sciences 4(3): 404408.

Dyte, C.E. and Forster, R. 1973. Studies on insecticide resistance in Oryzaephilus mercator (Fauv.) (Coleoptera, Silvanidae). 
Journal of Stored Products Research 9(3): 159-164.

Ebeling, W. 1971. Sorptive dust for pest control. Annual Review of Entomology 16: 123-158.

Faliki, A.M., Miko, S., Mohammed, I.B., Abubarka, I.U., Valentia, J.A. 2009. Evaluation of some improved bread wheat varieties at Chiyako, Jigawa State, Nigeria. Journal of Agriculture and Biological Sciences 4:1-4.

Fields, P.G. and Muir, W.E. 1996. Physical control: In: Integrated Management of Insects in Stored Products. Subramanyam B. and Hagstrum, D.W. (Eds.). Marcel Dekker, New York, USA. pp. 195-221.

Fields, P. and Korunic, Z. 2000. The effect of grain moisture content and temperature on the efficacy of diatomaceous earths from different geographical locations against stored product beetles. Journal of Stored Products Research 36(1):1-13.

Food and Agriculture Organization of the United Nations (FAO). 2008. World paddy production. http://www.fao.org/newsroom /en/news/2008/1000820/index.html. Accessed 26 March 2017.

Garcìa, M., Donael, O.J. Ardanaz, C.E., Tonn, C.E., and Sosa, M.E. 2005. Toxic and repellent effects of Baccharissa licifolia essential oil on Tribolium castaneum. Pest Management Science 61(6):612-618.

Goni, M and Amaza, P.S. 2006. Determinants of household food security in the Lake Chad area of Borno State, Nigeria. Journal of Research in Agriculture 3(4):29-34.

Habeeb, G.A. and Mahmud, H.B. 2010. Study on properties of rice husk ash and its use as cement replacement material. Material Research 13(2) São Carlos April/June 2010.

Kavallieratos, N.G., Athanassiou, C.G., Vayias, B.J. and Maistrou, S.N. 2007. Influence of temperature on susceptibility of Tribolium confusum (Coleoptera: Tenebrionidae) populations to three modified diatomaceous earth formulations. Florida Entomologist 90(4):616-625.

Korunic, Z. 1997. Rapid assessment of insecticidal value of diatomaceous earths without conducting bioassays. Journal of Stored Products Research 33(3):219-229.

Korunic, Z. I998. Diatomaceous earths, a group of natural insecticides. Journal of Stored Product Research 34(23):87-97.

Krishnamurthi, B and Rao, D.S. 1950. Some important insect pests of stored grains and their control. Agricultural College and Research Institute, Mysore India, Entomological Series, Belletin 14.

Madrid, R., Nogueira, C.A. and Margarido F. 2012. Production and characterisation of Amorphous Silica from rice husk waste. Proceedings of the International Conference on Engineering for Waste and Biomass Valorisation 4:10-13.

McCaffrey, B.J. 1979. Purely buoyant diffusion flames: Some experimental results (NBSIR 79-1910). United States National Bureau of Standards, Gaithersburg, MD, USA.

McFarlane, J.A. 1989. Guidelines for pest management research to reduce stored food losses caused by insects and mites. Bulletin, No. 22. Overseas Development Natural Resources Institute (ODNRI). $27 \mathrm{pp}$.

McLaughlin, A. 1994. Laboratory trials on desiccant dust insecticides. Proceedings of the International Working Conference on Stored Product Protection 6:638-645.

Nawrot, J., Malinski, E. and Szafranek, J. 1994. Function and composition of cuticular hydrocarbons of stored-product insects. Proceedings of the International Working Conference on Stored Product Protection 6:553-560.

Nwaubani, S.I. 2006. Evaluation of marble dust for the control of the maize weevil Sitophilus zeamais Motsch (Coleoptera: Curculionidae). Nigerian Journal of Entomology 23:1-5. 
Nwaubani, S.I. and Fasoranti, J.O., 2008. Efficacy of cow bone charcoal dust in the management of the maize weevil, Sitophilus zeamais Motsch. (Coleoptera: Curculionidae) and the Lesser Grain Borer, Rhyzopertha dominica Fab. (Coleoptera: Bostrichidae), infesting stored maize (Zea mays L.) grains. Nigeria Journal of Entomology 25:15-25.

Nwaubani, S.I., Opit, G.P., Otitodun, G.O. and Adesida, M.A. 2014. Efficacy of two Nigeria derived diatomaceous earths against Sitophilus oryzae (Coleoptera: Curculionidae) and Rhyzopertha dominica (Coleoptera: Bostrichidae) on wheat. Journal of Stored Products Research 59: 9-16.

Otitodun, G.O., Opit, G.P., Nwaubani, S.I., Okonkwo, E.U. and Gautam, S.G. 2015. Efficacy of Nigeria-derived diatomaceous earth, botanicals and riverbed sand against Sitophilus oryzae and Rhyzopertha dominica on wheat. African Crop Science Journal 23(3):279-293.

Rojht, H., Athanassiou, C.G., Vayias, B.J., Kavallieratos, N.G., Tomanoviæ, •., Vidrih, M., Kos, K. and Trdan, S. 2010. The effect of diatomaceous earth of different origin, temperature and relative humidity against adults of rice weevil Sitophilus oryzae (L.) (Coleoptera: Curculionidae) in stored wheat. Acta Agriculturae Slovenica 95:1320.
SAS Institute, 2013. The SAS system for Windows, version 9.4, SAS Institute, Cary, NC, USA.

Siddique, F. 2008. Waste materials and byproducts in concrete: With 174 tables. Springer Press.

Smith, R.G. and Kamwanja, G.A. 1986. The use of rice husk for making a cementitious material. In: Proceedings of the Joint Symposium on the Use of Vegetable Plants and their Fibers as Building Material, Bahgdad, Iraq 24.

Stathers, T.E. 2002. Combinations to enhance the efficacy of diatomaceous earths against the larger grain borer, Prostephanus truncatus (Horn). Proceedings of the International Working Conference on Stored Products Protection 8:925-929.

Subramanyam, B., Swanson, C.L., Madamanchi, N. and Norwood, S. 1994. Effectiveness of Insecto $^{\circledR}$, a new diatomaceous earth formulation in suppressing several stored grain insect species. Proceedings of the International Working Conference on Stored-Products Protection 6:650-659.

Winston, O.W. and Bates, D.H. 1960. Saturated solutions for the control of humidity in biological research. Ecology 42(2):232237.

Zhang, M.H. and Malhotra, V.M. 1996. Highperformance concrete incorporating rice husk ash as a supplementary cementing materials. ACI Materials Journal 93(6): 629-636. 